\title{
ЕКОНОМІКА
}

УДК 338.2:330.34:339.9

DOI: https://doi.org/10.26642/jen-2021-2(96)-3-8

Ю.П. Харченко, к.держ.упр.

Національний університет «Чернігівська політехніка»

\section{Домогосподарства та їх роль в інституціоналізації регіонального простору на засадах інклюзії}

У статті визначено сутність кониепту дослідження впливу домогосподарств як інститущіонального базису на інклюзивний регіональний розвиток в умовах модернізацї процесів державотворення в Україні. Вказано, щчо основою інклюзивного розвитку є рух знизу вгору, головною метою - побудова суспільства, пріоритетом - повне розкриття потенціалу людей $i$ створення рівних можливостей для кожної людини завдяки доступній та якісній освіті, розвиненій інфраструктурі й послугам охорони здоров'я. Інклюзивність означає те, щцо таку категорію, як економічний розвиток, відчувають на собі більшість членів суспільства не через збільшення доходів $i$ ВВП, а через розвиток людини, зниження ї̈ нерівності, підвищення особистого і суспільного добробуту. Інклюзивність економіки у ХХ столітті стала своєрідним оціночним явищем, яке надало реальних обрисів зростанню, розвитку чи споживанню, певним агрегованим показником, який бере до уваги не лише ВВП на душу населення, а й коефіцієнти розшарування суспільства за доходами $і$ розподілом багатства, рівнем бідності, рівнем медіанного доходу та інших показників, щзо враховують наступність поколінь і сталий розвиток.

Автор статті підтримує думку вітчизняних науковців про те, щчо рівень інклюзивності розвитку слід розглядати через таку інституцію, як аналіз домогосподарства. Реальне становище домогосподарств, їх роль у системі економічних відносин постійно змінюється, адже їх розвиток залежить від ступеня модернізаиії продуктивних сил. У статті зауважено, що саме домогосподарства можуть стати інклюзивною інститущією, яка з одного боку $\epsilon$ індикатором суспільної життєдіяльності, а з іншого впливає на інклюзивність регіонального розвитку, оскільки саме вони мають реальну можливість збільшувати власні доходи і циим самим підвищувати рівень родинного добробуту.

Наголошено на необхідності вибудовування державної політики щцодо сприяння росту всіх видів доходів. Визначено роль територіальних громад у задіянні громадського потенціалу для активізації інвестиційної діяльності та посилення використання внутрішніх ресурсів для підвищення темпів локалізаџії економічного простору.

Ключові слова: регіональний розвиток; інклюзивність; інситуціоналізація; модернізація регіонального розвитку; інституційний базис; домогосподарства.

Постановка проблеми. На етапі становлення нового регіоналізму особливої гостроти набуває необхідність інклюзивного підходу до генерації просторового регіонального розвитку в аспекті підвищення добробуту соціуму. Тобто існує нагальна потреба того, щоб переважна більшість членів громад мали можливість особисто відчути й оцінити результати економічного розвитку країни та ії регіонів. Тому новітні глобальні виклики спричинили появу поняття інклюзії не лише у науковому, а й у прикладному аспекті. Незважаючи на значну популярність вказаного терміну серед наукової еліти та досить поширене тиражування його у засобах масової інформації, категорія інклюзії не має однозначного й чіткого визначення, викликає взаємне нерозуміння його суті основними стейкхолдерами цього процесу.

Аналіз останніх досліджень та публікацій. Варто віддати належне іноземним дослідникам поняття «інклюзивності», адже основні положення зароджувалися переважно за кордоном. Зокрема, теоретичні основи інклюзивності розроблялися в наукових дослідженнях, над якими працювали: Д.Аджемоглу, Д.Робінсон, Е.С. Райнерт, Дж.Подест, 3.М. Бедос, С.Голандер та інші. Серед наших співвітчизників особливої уваги заслуговують наукові доробки О.М. Бородіної, Б.В. Буркинського, М.П. Бутка, В.М. Геєця, С.Й. Вовканича, А.А. Гриценка, Б.М. Данилишина, М.I. Мельник, С.I. Пирожкова, О.Д. Прогнімак, І.В. Прокопи, С.А. Романюка, В.Р. Сіденка, В.К. Симоненко, І.З. Сторонянської, С.Л. Шульц та інших. Проте більшість праць вітчизняних дослідників так чи інакше дотичні до питання результативності децентралізації як передумови інклюзивності, до практичних дій територіальних громад у соціогуманітарному середовищі, особливостей взаємовідносин між місцевими органами виконавчої влади та органами місцевого самоврядування. Однак щодо інституціонального базису сучасних процесів переформатування владних повноважень та результативності зазначеної діяльності 3 погляду інклюзивності, вседоступності та людиноцентризму, то сьогодні не досить ефективно ведеться практична імплементація цих напрямів у сферу діяльності місцевих органів публічної влади. Зокрема, вбачаємо потребу у більш детальному дослідженні впливу домогосподарств як базової інституції просторового розвитку на засадах інклюзії. 
Метою статті $\epsilon$ визначення сутності концепту дослідження впливу домогосподарств як інституціонального базису на інклюзивний регіональний розвиток в умовах модернізації процесів державотворення в Україні.

Викладення основного матеріалу. Проголошена реформа децентралізації в контексті розвитку людини, збереження ідентичності нації, історичних надбань, умінь та інтелектуального потенціалу має гармонізувати економічну, фіскальну i соціогуманітарну децентралізацію 3 потребами зовнішньоекономічної та політичної діяльності, національної оборони, зміцнення кордонів держави та євроінтеграційними процесами. У цьому контексті мова йде про інклюзивний розвиток, а враховуючи неоднозначність його трактування спробуємо проаналізувати генезу поняття. Зазначена дефініція в україномовній версії походить від англійського «inclusion» і у спрощеному розумінні означає залучення у різні сфери життя суспільства якомога більше соціуму без будь-яких обмежень [1].

Таке визначення стало наслідком того, що у вітчизняній економічній літературі замість терміну «інклюзія» часто вживають поняття «залучення» або «включення». Багатогранність поняття інклюзії проявляється в тому, що маючи широке значення воно застосовується у різних контекстах, таким чином в економічній літературі присутні різні його сполучення і аспекти: «інклюзивний розвиток», «інклюзивне зростання», «інклюзивна освіта», «фінансова інклюзія», «соціальна інклюзія» тощо.

Ідеями інклюзивності пронизані практично всі 17 Цілей сталого розвитку, затверджених підсумковим документом саміту ООН 2015 року «Перетворення нашого світу: порядок денний у сфері сталого розвитку до 2030 року». Серед вказаних важливих стратегічних цілей: подолання бідності; подолання голоду, досягнення продовольчої безпеки, поліпшення харчування і сприяння сталому розвитку сільського господарства; забезпечення здорового способу життя та сприяння благополуччю для всіх у будь-якому віці; забезпечення всеохоплюючої і справедливої якісної освіти та заохочення можливості навчання впродовж усього життя для всіх; забезпечення гендерної рівності, розширення прав і можливостей усіх жінок та дівчат; забезпечення доступності та сталого управління водними ресурсами та санітарією; забезпечення доступу до недорогих, надійних, стійких і сучасних джерел енергії для всіх; сприяння поступальному, всеохоплюючому та сталому економічному зростанню, повній і продуктивній зайнятості та гідній праці для всіх; створення стійкої інфраструктури, сприяння всеохоплюючій і сталій індустріалізації та інноваціям; скорочення нерівності; забезпечення відкритості, безпеки, життєстійкості й екологічної стійкості міст, інших населених пунктів; забезпечення переходу до раціональних моделей споживання і виробництва.

У вказаних положеннях невід'ємна частина цілей присвячена інклюзивному інституційному розвитку. Зокрема, сприянню побудові миролюбного і відкритого суспільства в інтересах усіх громадян, забезпеченню доступу до правосуддя для всіх і створенню ефективних, підзвітних та заснованих на широкій участі інституцій на всіх рівнях; зміцненню засобів здійснення й активізації роботи в межах глобального партнерства в інтересах сталого розвитку тощо. Україна, поряд з іншими країнами-членами ООН, приєдналася до глобального процесу забезпечення сталого розвитку та протягом 2016-2017 років адаптувала до національного законодавства цілі сталого розвитку. Враховуючи індивідуальність національного розвитку, вказані цілі були переглянуті та сформовані в національні завдання, які відображені в Національній доповіді «Цілі сталого розвитку: Україна».

Популярність застосування поняття інклюзивність чітко спостерігалася i на Всесвітньому економічному форумі в Давосі, де був запропонований Індекс інклюзивного росту та розвитку (Inclusive Growth and Development Index) як альтернативний до ВВП показник для віддзеркалення стану економічного розвитку країни через два аспекти: по-перше, через процес більшого залучення суб'єктів економіки до створення валового внутрішнього продукту, забезпечення рівних можливостей усіх верств суспільства для реалізації власного людського потенціалу й незалежно від конкретних соціальноекономічних умов, статі, віку, місця проживання, етнічної приналежності; по-друге, як стійке довгострокове економічне зростання з метою скорочення бідності й нерівності (Світовий банк, МВФ) [2].

Таким чином, інклюзивність означає, що таку категорію, як економічний розвиток, відчувають на собі більшість членів суспільства не через збільшення доходів і ВВП, а через розвиток людини, зниження iii нерівності, підвищення особистого і суспільного добробуту. Інклюзивність економіки у ХX столітті стала своєрідним оціночним явищем, яке надало реальних обрисів зростанню, розвитку чи споживанню, певним агрегованим показником, який бере до уваги не лише ВВП на душу населення, а й коефіцієнти розшарування суспільства за доходами і розподілом багатства, рівнем бідності, рівнем медіанного доходу та інших показників, що враховують наступність поколінь і сталий розвиток.

Аналізуючи узагальнені теоретичні підходи до поняття «соціальної інклюзії» є підстави визначати ії як спосіб усунення бар'єрів, якими є економічна нерівність і бідність, на шляху до участі й доступу до ресурсів і можливостей [4]; як процес, спрямований суспільством на боротьбу з бідністю і соціальним відторгненням [5].

Таким чином, незважаючи на багатоаспектність поняття «інклюзії», можна констатувати, що це сучасне явище суспільного життя у XXI столітті, яке вимагає грунтовніших досліджень його сутності, 
форм прояву та практичної реалізації. Основоположною в теорії інклюзії є ідея про те, що не особистість має пристосовуватися до економічних, соціальних, психологічних та інших проблем, а навпаки суспільство має створити рівні умови для задоволення потреб кожного його члена.

Основою інклюзивного розвитку є рух знизу вгору, головною метою - побудова суспільства, де пріоритетом $\epsilon$ повне розкриття потенціалу людей та створення рівних можливостей для кожної людини завдяки доступній та якісній освіті, розвиненій інфраструктурі та послугам охорони здоров'я. Іншими словами, формування громадянського суспільства й інклюзивних інституцій дозволяє всім громадянам брати участь у створенні ВВП та реалізовувати свій потенціал. Якість життя населення є всебічним показником розвитку всякої суспільної системи, оскільки є основним результатом і метою ії функцій.

Автор статті підтримує думку вітчизняних науковців, що рівень інклюзивності розвитку слід розглядати через таку інституцію, як аналіз домогосподарства. Реальне становище домогосподарств, їх роль у системі економічних відносин постійно змінюється, адже їх розвиток залежить від ступеня модернізації продуктивних сил. Тобто саме домогосподарства можуть стати інклюзивною інституцією, яка 3 одного боку є індикатором суспільної життєдіяльності, а 3 іншого впливає на інклюзивність регіонального розвитку, оскільки саме вони мають реальну можливість збільшувати власні доходи й цим самим підвищувати рівень родинного добробуту.

Давньогрецький мислитель Ксенофонт у трактаті «Домострой» описує зразкове домашнє господарство, надає характеристику економічним відносинам того часу через облаштування побуту, та аналізує їх економічну самостійність [5, с. 115].

Спробуємо розглянути основні аспекти діяльності домогосподарств як основної інституційної передумови інклюзивного регіонального розвитку в Україні в умовах децентралізації владних повноважень, враховуючи всі передумови їх формування та розвитку. При цьому під домогосподарством як інклюзивною інституцією слід розуміти групу людей, об'єднаних спільними завданнями відтворення людського потенціалу та його капіталізації, місцем проживання, бюджетом та сімейно-родинними зв'язками, до того ж, в інституціональній основі домашнього господарства лежать відносини власності, а контроль над економічною діяльністю передається одному з членів сім’ї.

Варто зауважити, що тривалий період функціонування командно-адміністративної системи витіснив діяльність домогосподарств, замінивши їх підприємствами державної форми власності, що значно погіршило стан домогосподарств та не давало можливості реалізувати повною мірою їх потреби й інтереси, що стало однією 3 перепон для розвитку національного виробництва. А термін «домашнє господарство» у вітчизняному науковому обігу з'явився лише у 2001 році. У Законі України «Про Всеукраїнський перепис населення», де домогосподарство розглядалося як «сукупність осіб, які спільно проживають в одному житловому приміщенні або його частині, забезпечують себе всім необхідним для життя, ведуть спільне господарство, повністю або частково об'єднують та витрачають кошти. Ці особи можуть знаходитися в споріднених зв'язках або у зв'язках свояків, не знаходитися ні в яких 3 цих зв'язків, або бути в тих і в інших. Домогосподарство може складатися з однієї особи» [6].

В своїх рекомендаціях ООН поняття «домогосподарство» визначає як «особу чи групу осіб, поєднаних з метою забезпечення всім необхідним для життя», тобто об'єднаних спільним веденням господарства. Часто термін «домогосподарство» ототожнюють 3 поняттям «сім'я», але вони не $\epsilon$ спорідненими. Розрізнити ці терміни можливо твердженням про відмінність між групою осіб, які ведуть спільне господарство, що виявляється у спільному виробництві та споживанні благ, з одного боку, і групою родичів 3 другого. Крім того наголос робиться саме на тому, що члени сім'ї не обов'язково живуть разом і мають спільний бюджет. Важливим дефініційним моментом $є$ те, що домогосподарство має визначені територіальні межі, до нього можуть належати члени, що не є родичами, а також воно передбачає існування внутрішніх економічних відносин (власності, розподілу праці, бюджетних відносин, відносин влади тощо) [7].

Аналіз наукової літератури та нормативно-правових актів свідчить про те, що нині існує практика розуміння поняття «домогосподарства», яке співзвучне із загальноприйнятими міжнародними стандартами й трактує домогосподарство як економічний суб'єкт, що складається з однієї або кількох осіб, які проживають в одному житловому приміщенні, ділять спільний побут, постачають на відповідні ринки різноманітні ресурси та спільно приймають економічні рішення щодо формування своїх доходів і здійснення витрат з метою задоволення власних матеріальних і духовних потреб, тобто спільно здійснюють господарську діяльність та мають спільний бюджет.

На переконання автора статті, домогосподарство - це не лише економічна одиниця, що складається 3 однієї або більше осіб; постачає економіку ресурсами й використовує отримані доходи для купівлі товарів і послуг, які задовольняють потреби людини, а й інституційна передумова інклюзивного регіонального розвитку та підвищення добробуту населення України.

Стан сучасної економіки свідчить про те, що домогосподарства відіграють провідну роль у іiі формуванні. Оскільки левова частка ВВП створюється в секторі підприємств різних форм власності, то споживання отриманих матеріальних благ насамперед відбувається в секторі домогосподарств. 
Домогосподарства певну частку внутрішнього продукту виробляють, але існує тенденція: чим більш розвинута економіка тієї чи іншої країни, тим менша частка ВВП виробляється домогосподарствами, які більше зосереджені на споживанні. В Україні домогосподарства виробляють в першу чергу продукцію сільського господарства, зокрема особисті селянські господарства, які продукують значну частку тваринництва й овочівництва, при цьому виробнича активність домогосподарств $\epsilon$ джерелом самозайнятості. Держстатом України для оцінки рівня розвитку домогосподарств використовується система показників, що складається з: 1) грошових доходів; 2) негрошових доходів; 3) загальних доходів; 4) сукупних ресурсів [8]. Основним видом витрат домогосподарств є: витрати на придбання товарів і послуг (споживчі) та поточні трансферти (податки і добровільні платежі та заощадження).

Рівень доходів і структура витрат домогосподарств тісно взаємопов'язані й саме вони характеризують інклюзивну стратифікацію регіонального ландшафту. Уперше це дослідив Е.Енгель, який стверджував, що зі зростанням доходу частка витрат на харчування зменшується; витрати на одяг, житло, опалення й освітлення змінюються порівняно менше, несуттєво; а частка витрат на задоволення культурних та інших нематеріальних потреб помітно збільшується. Потреби споживачів задовольняються від простіших до вищих і залежно від доходів. Сім'ї з низькими доходами витрачають більшу їх частину на харчування, одяг, житло. Ця закономірність, яка отримала назву «закон Енгеля», визначає еластичність попиту щодо доходу [9, с. 357]. Згідно із законом Енгеля витрати на придбання товарів першої необхідності скорочуються зі зростанням величини доходів. Основним твердженням вказаного закону є те, що родини 3 малими статками більше коштів витрачають на товари першої необхідності, житло, їжу, а за збільшення доходів частка витрат на житло та харчування зменшується. Що ж стосується витрат на дороговартісні предмети, то вони зростають швидше, ніж дохід; споживання вторинних благ зростає більше, ніж споживання благ першої необхідності.

Аналіз структури доходів і витрат домогосподарств як базової інституції модернізаційного стану засвідчив, що нині державна політика не сприяє їх позитивному впливу на рівень інклюзивності сталого розвитку регіонального ландшафту України. Зокрема, рівень сукупних ресурсів у середньому за місяць має тенденцію до зростання (табл. 1).

Таблиия 1

Динаміка і структура ресурсів домогосподарств

\begin{tabular}{|c|c|c|c|c|c|c|}
\hline $\begin{array}{ll}\text { Ресурси } & \text { Рік } \\
\end{array}$ & 2013 & 2014 & 2016 & 2017 & 2018 & 2019 \\
\hline $\begin{array}{l}\text { Сукупні ресурси в середньому за місяць у } \\
\text { розрахунку на одне домогосподарство, грн }\end{array}$ & 4470,5 & 4563,3 & 6238,8 & 8165,2 & 9904,1 & 12118,5 \\
\hline \multicolumn{7}{|l|}{$\begin{array}{l}\text { Структура сукупних ресурсів } \\
\text { домогосподарств, \% }\end{array}$} \\
\hline Грошові доходи: & 90,8 & 91,2 & 86,0 & 87,5 & 89,9 & 92,0 \\
\hline - оплата праці & 50,6 & 48,8 & 46,7 & 52,4 & 54,5 & 57,3 \\
\hline $\begin{array}{l}\text { - доходи від підприємницької діяльності та } \\
\text { самозайнятості }\end{array}$ & 4,1 & 5,2 & 5,2 & 4,4 & 6,0 & 6,5 \\
\hline $\begin{array}{l}-\quad \text { доходи від продажу } \\
\text { сільськогосподарської продукції }\end{array}$ & 2,8 & 3,2 & 2,9 & 3,0 & 2,5 & 2,4 \\
\hline $\begin{array}{l}\text { - } \text { пенсії, стипендії, соціальні допомоги, } \\
\text { надані готівкою }\end{array}$ & 27,1 & 27,0 & 23,1 & 20,2 & 19,9 & 19,2 \\
\hline $\begin{array}{l}\text { - грошова допомога від родичів, інших } \\
\text { осіб та інші грошові доходи }\end{array}$ & 6,2 & 7,0 & 8,1 & 7,5 & 7,0 & 6,6 \\
\hline $\begin{array}{l}\text { Вартість спожитої продукції, отриманої з } \\
\text { особистого підсобного господарства та від } \\
\text { самозаготівлі }\end{array}$ & 3,9 & 4,6 & 4,8 & 4,0 & 3,8 & 3,6 \\
\hline $\begin{array}{l}\text { Пільги та субсидії безготівкові на оплату } \\
\text { житлово-комунальних послуг, } \\
\text { електроенергії, палива }\end{array}$ & 0,4 & 0,4 & 4,7 & 4,7 & 2,8 & 0,7 \\
\hline $\begin{array}{l}\text { Пільги безготівкові на оплату товарів та } \\
\text { послуг з охорони здоров’я, туристичних } \\
\text { послуг, путівок на бази відпочинку тощо, на } \\
\text { оплату послуг транспорту, зв’язку }\end{array}$ & 0,5 & 0,4 & 0,4 & 0,4 & 0,4 & 0,4 \\
\hline Інші надходження & 4,4 & 3,4 & 4,1 & 3,4 & 3,1 & 3,3 \\
\hline
\end{tabular}

Джерело: розроблено автором на основі [10] 
Водночас не менш вагомою складовою доходів населення є соціальні допомоги, доходи від продажу сільськогосподарської продукції, пенсії, стипендії, соціальні допомоги, надані готівкою, грошова допомога від родичів, інших осіб. Така ситуація свідчить про те, що в середньому третина доходів населення поповнюється за рахунок грошових виплат і допомог від держави. На прибуток та змішаний дохід, зокрема у 2018 році, припадало 17,6 \% усіх грошових доходів населення, на доходи від власності (одержані) - лише 2,6 \%. Основним джерелом доходів населення є оплата праці та пенсії: у 2018 році їх питома вага у структурі грошових доходів домогосподарств становила 60,5 \% та 19,5 \% відповідно. Незначну частку доходів (6,6 \%) отримано домогосподарствами від підприємницької діяльності та самозайнятості. Значна кількість виробництва сільськогосподарської продукції припадає саме на домогосподарства. Обсяги виробництва сільськогосподарської продукції наведено у таблиці 2.

Таблиия 2

Обсяги виробництва сільськогосподарської продукиії у домогосподарствах України

\begin{tabular}{|c|c|c|c|c|c|}
\hline Вид продукції & 1990 & 2000 & 2010 & 2015 & 2019 \\
\hline \multicolumn{6}{|c|}{ у\% до загального обсягу виробництва всіма категоріями господарств } \\
\hline Картопля & 71,4 & 98,6 & 97,4 & 97,8 & 98,2 \\
\hline Культури овочеві & 26,9 & 83,1 & 88,1 & 86,1 & 85,3 \\
\hline Культури плодові та ягідні & 53,6 & 81,8 & 83,6 & 80,9 & 83,4 \\
\hline Культури зернові та зернобобові & 2,8 & 18,4 & 24,2 & 22,7 & 20,2 \\
\hline Молоко & 24,0 & 71,0 & 80,3 & 74,9 & 71,8 \\
\hline М’ясо (у забійній масі) & 28,9 & 73,7 & 44,9 & 37,0 & 31,9 \\
\hline
\end{tabular}

Джерело: розроблено автором

Висновки. Децентралізаційні зміни торкнулися не лише регіону як об'єкта державної політики, оскільки зі зростанням мобільності ресурсів, капіталів, товарів і послуг значно знецінилися чинники географічного розташування та територіальної близькості. Дослідження впливу домогосподарств як інституціонального базису на інклюзивний регіональний розвиток в умовах модернізації процесів державотворення в Україні доводить, що такі економіко-географічні чинники конкурентоспроможності регіонів, які вважалися традиційними, як наявність природних, трудових та енергетичних ресурсів, якість наявного матеріального капіталу тощо, втрачають значущість для просторового розвитку, натомість домогосподарства здобувають більш вагомий потенціал. Важливою $є$ роль територіальних громад у задіянні громадського потенціалу 3 метою активізації інвестиційної діяльності. Водночас активізація використання внутрішніх ресурсів для підвищення темпів локалізації економічного простору в цілому сприятиме модернізації продуктивних сил регіону.

\section{Список використаної літератури:}

1. Бутко М.П. Біфуркаційний стан державотворчого ядра України в умовах реалізації євроінтеграційного курсу / М.П. Бутко // Економіка України. - 2017. - № 10. - С. 49-64 [Електронний ресурс]. - Режим доступу : http://nbuv.gov.ua/UJRN/EkUk_2017_10_5.

2. Базилюк A.B. Інклюзивне зростання як основа соціально-економічного розвитку / А.В. Базилюк, O.В. Жулин // Економіка та управління на транспорті. - 2015. - Вип. 1. - С. 19-29.

3. Інклюзивність економіки - нове мірило економічного росту : матеріали Київського міжнародного економічного форуму, 09.07.2017 [Електронний ресурс]. - Режим доступу : http://forumkyiv.org/uk/news/inkljuzivnist-ekonomiki-nove-mirilo-ekonomichnogo-rostu.

4. Попова Т.Л. Соціальне залучення: концептуальні підходи до визначення / T.Л. Попова // Державне управління: теорія та практика. - 2013. - № 1 [Електронний ресурс]. - Режим доступу: http://academy.gov.ua/ej/ej17/PDF/16.pdf.

5. Мочерний С.В. Політична економія : навч. посіб. / С.В. Мочерний. - Київ : Знання\#Прес, 2002. -687 с

6. Закон України «Про Всеукраїнський перепис населення» // Відомості Верховної Ради України. - 2000. № 51-52.

7. Шевченко Л.С. Основи економічної теорії / Л.С. Шевченко [Електронний ресурс] - Режим доступу: http://uristinfo.net/uchebnye-materialy/280-osnoviekonomichnoyi-teoriyi--ls-shevchenko-/8812-glava-9domogospodarstvo-jak-subekt-rinkovihvidnosin.html.

8. Офіційний сайт Державної служби статистики України [Електронний ресурс]. - Режим доступу: http://www.ukrstat.gov.ua/.

9. Фінанси : підручник / за ред. С.І. Юрія, В.М. Федосова. - Київ : Знання, 2008. - 611 с.

10. Статистичний збірник «Сільське господарство України» / Державна служба статистики України [Електронний ресурс]. - Режим доступу : http://www.ukrstat.gov.ua/druk/publicat/Arhiv_u/07/Arch_sg_zb.htm. 


\section{References:}

1. Butko, M.P. (2017), «Bifurkacijnyj stan derzhavotvorchogo jadra Ukrai'ny v umovah realizacii' jevrointegracijnogo kursu», Ekonomika Ukrai'ny, No. 10, pp. 49-64, [Online], available at: http://nbuv.gov.ua/UJRN/EkUk_2017_10_5

2. Bazyljuk, A.V. and Zhulyn, O.V. (2015), «Inkljuzyvne zrostannja jak osnova social'no-ekonomichnogo rozvytku», Ekonomika ta upravlinnja na transporti, Issue 1, pp. 19-29.

3. «Inkljuzyvnist' ekonomiky - nove mirylo ekonomichnogo rostu», Kyi'vs'kyj mizhnarodnyj ekonomichnyj forum, 09.07.2017, [Online], available at: http://forumkyiv.org/uk/news/inkljuzivnist-ekonomiki-nove-miriloekonomichnogo-rostu

4. Popova, T.L. (2013), «Social'ne zaluchennja: konceptual'ni pidhody do vyznachennja», Derzhavne upravlinnja: teorija ta praktyka, No. 1, [Online], available at: http://academy.gov.ua/ej/ej17/PDF/16.pdf

5. Mochernyj, S.V. (2002), Politychna ekonomija, navch. posib., Znannja\#Pres, Kyi'v, 687 p.

6. Verhovna Rada Ukrai'ny (2000), «Zakon Ukrai'ny «Pro Vseukrai'ns'kyj perepys naselennja», Vidomosti Verhovnoi' Rady Ukrai'ny, No. 51-52.

7. Shevchenko, L.S., Osnovy ekonomichnoi' teorii', [Online], available at: http://uristinfo.net/uchebnye-materialy/280osnoviekonomichnoyi-teoriyi--ls-shevchenko-/8812-glava-9-domogospodarstvo-jak-subekt-rinkovihvidnosin.html

8. Oficijnyj sajt Derzhavnoi' sluzhby statystyky Ukrai'ny, [Online], available at: http://www.ukrstat.gov.ua/

9. Jurij, S.I. and Fedosov, V.M. (ed.) (2008), Finansy, pidruchnyk, Znannja, Kyi'v, 611 p.

10. Derzhavna sluzhba statystyky Ukrai'ny, Statystychnyj zbirnyk «Sil's'ke gospodarstvo Ukrai'ny», [Online], available at: http://www.ukrstat.gov.ua/druk/publicat/Arhiv_u/07/Arch_sg_zb.htm

Харченко Юлія Петрівна - кандидат наук з державного управління, доцент кафедри менеджменту та державної служби Національного університету «Чернігівська політехніка».

https://orcid.org/0000-0001-6181-548X.

Наукові інтереси:

- регіональна економіка.

E-mail: ycharhenkoyp@gmail.com.

Стаття надійшла до редакції 05.05.2021. 